\title{
METODE PEMBELAJARAN PQ4R DALAM PENINGKATAN KEMAMPUAN MEMBACA PEMAHAMAN SISWA KELAS V DI BEKASI
}

\author{
Rima Rikmasari, Mega Lestari \\ Universitas Islam 45 Bekasi \\ Email: r.rikmasari@gmail.com
}

Naskah diterima : 5 Oktober 2018, direvisi : 10 Oktober 2018, disetujui : 21 Oktober 2018

\begin{abstract}
The aim of this study is to determine the application of learning methods PQ4R (Preview, Question, Read, Reflect, Recite, Review) in reading comprehension of the fifth grade students in Indonesian lesson at SDN Cibuntu 06 Bekasi. The results showed that there was an increasing students' reading comprehension ability in each cycle, the first cycle classical completeness of $67.64 \%$ with an average value of 80.17 , in the second cycle classical completeness reached $76.47 \%$ with an average value of 80,55 and in cycle III classical completeness increased to $94.11 \%$ with an average student score of 84.61 . The study means that to improve students' reading comprehension skills in Indonesian subjects can be applied the methods PQ4R (Preview, Question, Read, Reflect, Recite, Review)
\end{abstract}

Key Words: PQ4R Method, Reading Comprehension

Pengutipan: Rima Rikmasari, Mega Lestari. (2018). Metode Pembelajaran PQ4R dalam Peningkatan Kemampuan Membaca Pemahaman Siswa Kelas $V$ di Bekasi. JMIE: Journal of Madrasah Ibtidaiyah Education, 2(2), 2018, 265-275. jmie.v2i2.78.

Permalink/DOI: http://dx.doi.org/ 10.32934/jmie.v2i2.78 


\section{PENDAHULUAN}

Bahasa merupakan komunikasi yang dilakukan setiap individu dalam berinterkasi anatar satu dengan yang lainnya. Bahasa yang digunakan salah satunya adalah Bahasa Indonesia. Dimana tujuan pembelajaran bahasa Indonesia dalam Standar Isi (2007:317) adalah: (1) berkomunikasi secara efektif dan efisien sesuai dengan etika yang berlaku baik secara lisan maupun tulis, (2) menghargai dan bangga menggunakan bahasa Indonesia sebagai bahasa persatuan dan bahasa negara, (3) memahami bahasa Indonesia dan menggunakannya dengan tepat dan kreatif untuk berbagai tujuan, (4) menggunakan bahasa Indonesia untuk meningkatkan kemampuan intelektual, serta kematangan emosional dan sosial, (5) menikmati dan memanfaatkan karya sastra untuk memperluas wawasan; memperhalus budi pekerti; serta meningkatkan pengetahuan; dan kemampuan berbahasa, (6) menghargai dan membanggakan sastra Indonesia sebagai khazanah budaya dan intelektual manusia Indonesia.

Menurut Tarigan 2008:1, keterampilan berbahasa (atau language arts, language skills) dalam kurikulum di sekolah biasanya mencakup empat segi, yaitu: 1) Keterampilan menyimak atau mendengarkan (listening skills), 2) Keterampilan berbicara (speaking skills), 3) Keterampilan membaca (reading skills), 4) Keterampilan menulis (writing skills). Dari ketiga keterampilan tersebut memiliki keterkaitan atau hubungan yang cukup erat dan beraneka ragam. Seperti dalam memperoleh keterampilan berbahasa biasanya dilakukan secara berurutan khususnya pada anak kecil. Awalnya dengan melakukan kegiatan menyimak dan mendengarkan pembicaraan orang-orang yang ada di sekitarnya, kemudian menirukan pembicaraan tersebut, setelah itu baru belajar membaca dan menulis dengan baik. oleh karena itu sering disebut anak kecil merupakan peniru yang ulung, dia akan menirukan apapun yang didengar dari orangorang sekelilingnya.

Menurut Suyatmi (2010:39), kegiatan membaca dapat dibedakan menjadi beberapa macam. Hal ini dapat dilihat dari segi tinjauannya. Ada dua jenis tinjauan yang berkaitan dengan jenis-jenis membaca antara lain: (1) menurut segi teknik, dan (2) menurut segi tatarannya. Membaca dari segi teknik adalah terdengar atau tidaknya suara si pembaca saat melakukan aktivitas membaca. Dilihat dari segi ini membaca dibedakan menjadi dua, yaitu membaca dalam hati dan membaca nyaring. Pada membaca dalam hati, pembaca menggunakan ingatan visual dalam arti keaktifan terletak pada penglihatan dan ingatan. Pada membaca nyaring, selain menggunakan penglihatan dan ingatan, dituntut pula keaktifan pendengaran. 
Menurut tatarannya, kegiatan membaca dapat dibedakan menjadi 2 macam, yaitu membaca permulaan dan membaca lanjut. Membaca permulaan adalah suatu jenis membaca yang hanya mementingkan kelancaran suara saja. Membaca jenis ini biasa dilakukan pada saat anak masih duduk di kelas 1 dan 2 SD. Membaca lanjut merupakan kegiatan membaca yang bukan hanya mementingkan kelancaran saja, tetapi juga pemahaman dan penerapan dalam praktik hidup sehari-hari sesuai dengan situasi dan kondisi.

Soedarso, (dalam Fudizri, 2014:13-14) membaca pemahaman merupakan kemampuan membaca untuk mengerti ide pokok dan detail yang penting dari keseluruhan isi bacaan. Membaca pemahaman merupakan salah satu dari kegiatan membaca yang bertujuan untuk memahami isi yang terdapat dalam bacaan. Untuk pemahaman perlu perbendaharaan kata dan akrab dengan struktur dasar penulisan yang terdiri dari kalimat, paragraf, dan tatabahasa.

Kemampuan membaca pemahaman sangat penting peranannya dalam membantu anak mempelajari berbagai hal. Melalui aktivitas membaca yang baik dan benar diharapkan anak mampu mengambil intisari bacaan yang dibacanya, sehingga mendapatkan sesuatu dari aktivitas membaca yang ia lakukan. Semakin banyak intisari yang bisa dipahami dari bahan bacaannya maka semakin banyak pula kemampuan yang anak peroleh. Sampai di sini, jelaslah bahwa kemampuan membaca anak sangat penting peranannya bagi keberhasilan dirinya sendiri, bahkan bisa mempengaruhi kemajuan negaranya.

Berdasarkan hasil observasi dan wawancara yang dilakukan peneliti pada siswa kelas V SDN Cibuntu 06 terdapat kondisi awal siswa pada tes kemampuan membaca pemahaman dengan ketuntasan klasikal sebesar 20,58\%, diketahui rata-rata keseluruhan nilai siswa pada kondisi awal yaitu 69, hanya terdapat 7 siswa yang tuntas dan 27 siswa lainnya belum tuntas. Berdasarkan hasil kondisi awal tersebut terdapat Beberapa masalah mengenai aspek membaca pemahaman dalam pembelajaran Bahasa Indonesia. Masalah yang ditemui dalam membaca pemahaman yaitu Pertama, siswa belum mampu dalam mencari pengertian sederhana dalam teks bacaan. Kedua, siswa kurang memahami makna dalam teks bacaan. Ketiga, siswa kurang memahami soal yang diberikan selesai membaca teks bacaan. Keempat, kecepatan membaca yang dilakukan siswa kurang lancar dan cenderung lambat. kelima, kurangnya pusat perhatian siswa karena metode pembelajaran yang digunakan kurang menarik.

Berdasarkan uraian diatas maka peneliti memilih metode pembelajaran yang efektif dan cocok untuk meningkatkan kemampuan membaca pemahaman belajar 
siswa dengan metode pembelajaran PQ4R (Preview, Question, Read, Reflect, Recite, dan Review). Karena, menurut beberapa teori metode PQ4R sangat cocok untuk meningkatkan kemampuan membaca pemahaman, yaitu di setiap tahapan pembelajarannya mampu memotivasi siswa untuk mencari, mengingat, dan memahami informasi yang didapat dari hasil membaca cerita atau bahan bacaan lainnya. Adapun beberapa kelebihan yang mendasari penggunaan metode PQ4R untuk meningkatkan kemampuan membaca pemahaman, yaitu a) siswa mengetahui kiat-kiat membaca cepat agar mudah mengingat dan memahami bacaan, b) siswa dilatih untuk lebih mudah menemukan gagasan utama atau ide pokok sebuah cerita, c) siswa dilatih untuk membuat ringkasan cerita dengan mudah dan tepat.

Menurut Trianto, (2012: 150) metode Preview Question Read Reflect Recite Review merupakan salah satu bagian dari strategi elaborasi yang membantu pemindahan informasi baru dari memori jangka pendek ke memori jangka panjang dengan menambahkan perincian informasi baru melalui tahap Preview (membaca selintas), Question (bertanya), Read (membaca), Reflect (refleksi), Recite (tanya jawab sendiri), dan Review (mengulang secara menyeluruh). Perincian informasi dapat membantu siswa mengingat apa yang mereka baca.

Melalui tahap-tahap metode Preview Question Read Reflect Recite Review kegiatan membaca siswa lebih terarah dengan tujuan jelas yaitu menemukan informasi dari bacaan sesuai dengan pertanyaan yang telah dibuat sebelum membaca. Pertanyaanpertanyaan tersebut dapat membantu siswa merinci informasi yang mereka peroleh dari bacaan sehingga memudahkan siswa untuk menyusun kesimpulan dari bacaan. Selain itu kegiatan membaca siswa lebih bermakna karena siswa dilatih untuk bersifat kritis dengan menanggapi isi bacaan dan menghubungkan isi bacaan dengan materi yang telah dipelajari sebelumnya.

Menurut Mulipah, 2011: 56 kelebihan metode Preview Question Read Reflect Recite Review adalah mengaktifkan siswa, sistematis, praktis, tidak menjenuhkan, menimbulkan kedekatan antara guru dan siswa, dan bermakna yaitu siswa tidak hanya hafal dengan bacaan tapi mampu memahami isi bacaan.

Penelitian yang relevan dengan masalah di atas, Nurma (2013) pernah melakukan penelitian dengan judul "Penerapan Strategi PQ4R untuk Meningkatkan Keterampilan Membaca Pemahaman Pada Siswa Kelas VA SD Bojong Salaman 02 Semarang" yang menyimpulkan bahwa strategi pembelajaran PQ4R yang ditetapkan oleh guru dapat meningkatkan penguasaan pembelajaran membaca pemahaman. Hal ini terbukti dengan praktik yang dilakukan oleh siswa dalam melakukan strategi 
pembelajaran PQ4R dalam kelompok. Hasil penelitiannya menunjukkan bahwa Pada siklus I pertemuan 1 jumlah nilai rata-rata siswa 63,16 dan pada siklus I pertemuan 2 jumlah rata-rata siswa meningkat menjadi 70. Jadi rata-rata nilai siklus I siswa memperoleh nilai rata-rata 66,56. Selanjutnya pada siklus II pertemuan 1 siswa memperoleh jumlah nilai rata-rata 67,33 dan pada siklus II pertemuan 2 jumlah nilai rata-rata meningkat menjadi 72,16 . Jadi rata-rata nilai siklus II siswa memperoleh nilai rata-rata 69,75 .

Berdasarkan penelitian yang sudah diketahui keberhasilan maka peneliti mengambil judul "Penerapan Metode Pembelajaran PQ4R (Preview, Question, Read, Reflect, Recite, Review) dalam Meningkatkan Kemampuan Membaca Pemahaman Pada Pembelajaran Bahasa Indonesia Siswa Kelas V SDN Cibuntu 06 Kabupaten Bekasi”.

Metode pembelajaran PQ4R dikembangkan oleh Thomas dan Robinson (1972) yang merupakan penyempurnaan dari metode SQ3R (Robinson 1961, dalam Trianto 2014:178). Seiring dengan perkembangan zaman, ternyata metode SQ3R masih belum sempurna, karena masih dibutuhkan sebuah langkah lagi yaitu Reflect (refleksi), guna untuk mengembangkan informasi apa saja yang ada pada cerita atau bahan bacaan dan memindahkannya dari memori jangka pendek ke memori jangka panjang. Oleh karena itulah timbul metode pembelajaran PQ4R pengembangan dari metode pembelajaran SQ3R.

Menurut Arends (dalam Trianto, 2007:147) metode PQ4R merupakan salah satu metode membaca yang digunakan untuk membantu siswa memahami dan mengingatkan materi yang mereka baca. Jadi metode PQ4R yaitu suatu metode membaca yang digunakan untuk membantu siswa berpikir kritis dan memanfaatkan daya ingat siswa yang dapat membantu siswa memahami suatu bacaan.

\section{METODE PENELITIAN}

Penelitian ini dilakukan di SDN Cibuntu 06 yang berlokasi di daerah Kabupaten Bekasi. Waktu penelitian dilaksanakan pada tahun ajaran 2017/2018, tepatnya dilaksanakan pada bulan september 2017.

Metode penelitian yang digunakan oleh peneliti ini adalah metode penelitian tindakan kelas (PTK). Kemmis dan Mc Taggart, (dalam Saur Tampubolon, 2014:19) penelitian tindakan kelas merupakan bentuk strategi dalam mendeteksi dan memecahkan masalah yang dihadapi pendidik dengan tindakan nyata, yaitu melalui prosedur penelitian yang berbentuk siklus (daur ulang). 
Dalam penelitian ini dapat dua variabel yaitu, variabel bebas (Independen $V$ ariabel) sebagai variabel $\mathrm{X}$ dan variabel terikat (Dependen Variabel) sebagai variabel $\mathrm{Y}$ sebagai berikut : 1) Variable X, yaitu Metode PQ4R (Preview, Question, Read, Reflect, Recite, Review) 2) Variable Y, yaitu Kemampuan Membaca Pemahaman. Instrumen dalam penelitian ini terbagi menjadi dua yaitu: 1) tes tertulis dan tes unjuk kerja untuk kemampuan membaca pemahaman,

2) lembar observasi untuk melihat guru dalam menerapkan metode PQ4R. Uji validitas ahli yaitu menggunakan Expert judgment.

\section{HASIL DAN PEMBAHASAN}

Hasil tes kemampuan membaca pemahaman siswa pada mata pelajaran Bahasa Indonesia siklus I, siklus II dan siklus III mengalami peningkatan yang cukup memuaskan. Peningkatan tersebut terlihat dari peningkatan nilai rata-rata kemampuan membaca pemahaman siswa pada mata pelajaran Bahasa Indonesia. Peneliti melaksanakan tindakan pembelajaran dengan menggunakan metode PQ4R (Preview, Question, Read, Reflect, Recite, Review) sesuai dengan rencana pembelajaran yang telah disusun.

Materi yang diajarkan adalah membaca dan memahami teks bacaan tentang "menonton tv". Pembelajaran dibuka oleh peneliti dengan mengucapkan salam yang dilanjutkan dengan pengkondisian siswa dengan berdoa bersama kemudian peneliti mengecek kehadiran siswa. Sebelum masuk kepada materi pelajaran, peneliti memberikan motivasi dan tujuan pmbelajaran hari ini.

Siswa dibentuk menjadi 6 kelompok belajar, masing-masing siswa diberikan teks bacaan menonton $\mathrm{t}$, dan masing-masing kelompok diberikan kertas selembar untuk menerapkan metode PQ4R (Preview, Question, Read, Reflect, Recite, Review). Pada tahap Preveiw siswa diminta membaca sekilas teks bacaan "menonton tv" secara serentak di dalam hati, kemudian guru menghitung kecepatan membaca siswa dengan menggunakan stopwatch selama satu menit, ketika sudah mencapai satu menit guru langsung meminta siswa berhenti membaca dan memberikan tanda $(\checkmark)$ pada bacaan yang mereka baca.

Setelah siswa melakukan tahap Preview, masing-masing siswa di masing-masing kelompok diminta untuk menemukan gagasan utama pada bacaan yang telah mereka baca. Setelah melakukan tahap preview, siswa diminta melakukan tahap Question yaitu masing-masing kelompok diminta untuk berdiskusi membuat pertanyaan sebanyak 5 pertanyaan selama 3 menit kemudian ditulis di kertas selembar yang 
diberikan guru. Setelah melakukan tahap question, siswa diminta untuk melakukan tahap Read yaitu membaca teks bacaan secara keseluruhan dengan cermat dan tepat agar bisa memahami isi bacaannya, setelah membaca siswa diminta menjawab pertanyaan-pertanyaan yang telah mereka buat sebelumnya secara kelompok dengan berdiskusi dalam waktu 3 menit. Setelah melakukan tahap Read, siswa diminta melakukan tahap Reflect yaitu siswa diminta menghubungkan isi cerita dengan kehidupan sehari-hari yaitu guru mengajukan beberapa pertanyaan mengenai isi cerita untuk dikaitkan ke kehidupan sehari-hari yang bertujuan untuk membuat siswa memahami isi bacaan dengan lebih mudah.

Setelah melakukan tahap Reflect, siswa diminta melakukan tahap Recite yaitu masingmasing kelompok menuliskan kesimpulan atau ringkasan cerita di kertas selembar yang diberikan guru dengan berdiskusi selama 3 menit. Setelah melakukan tahap Recite, siswa diminta melakukan tahap Review yaitu meninjau ulang isi teks bacaan secara keseluruhan dengan mengajukan beberapa pertanyaan kepada siswa di masing-masing kelompok untuk mengetahui sejauh mana siswa memahami teks bacaan yang telah dibaca. Setelah semua tahapan metode PQ4R (Preview, Question, Read, Reflect, Recite, Review) dilakukan peneliti dan siswa menyimpulkan materi secara keseluruhan, kemudain melakukan sesi tanya jawab. Setelah melakukan sesi tanya jawab, peneliti memberikan tes tertulis tentang teks bacaan "menonton tv" untuk mengukur kemampuan membaca pemahaman siswa, siswa diberikan waktu selama 30 menit untuk mengerjakannya.

Pada siklus I nilai rata-rata yang diperoleh siswa sebesar 80,17 yang kemudian mengalami peningkatan pada siklus II menjadi 80,55 dengan presentase ketuntasan klasikal pada siklus I sebesar 67,64\% menjadi 76,47\%. Peningkatan ini disebabkan pemberian tindakan siklus II dengan memberikan tambahan waktu kepada siswa untuk memahami isi teks bacaan yang dibaca dan untuk latihan tes tulis dimana pada siklus I hanya diberikan waktu 20 menit, untuk meningkatkan presentase ketuntasan peneliti menambahkan waktu pada siklus II menjadi 30 menit.

Pada siklus III nilai rata-rata yaitu 84,61 dengan presentase ketuntasan klasikal meningkat, dari sebelumnya $76,47 \%$ menjadi sebesar $94,11 \%$ pada siklus III. Peningkatan ini dipengaruhi oleh persiapan peneliti yang lebih matang, peneliti juga memberikan tambahan waktu untuk memahami isi bacaan, membaca cepat bacaan dengan rata-rata sebanyak 75 kata selama satu menit dan untuk tes tulis yang semula hanya 20 menit menjadi 30 menit pada siklus III. 
Tabel.1 peningkatan pemahaman membaca

\begin{tabular}{cccl}
\hline & Siklus I & Siklus II & Siklus III \\
\hline Rata-rata & 80,17 & 80,55 & 84,61 \\
Presentase Ketuntasan & $67,64 \%$ & $76,47 \%$ & $94,11 \%$ \\
\hline
\end{tabular}

Selain itu peneliti juga memberikan treatment yang tepat dengan melakukan penjelasan ulang mengenai indikator yang dirasa masih menjadi kendala yang dihadapi siswa, siswa pun sudah dapat mengikuti pembelajaran dengan baik sehingga hasil yang didapatkan pun meningkat. Penelitian berhenti cukup sampai disiklus III. Hal ini di karenakan di siklus III indikator keberhasilan penelitian sudah tercapai dan hasilnya pun sangat memuaskan, sehingga penelitian tindakan kelas ini hanya dilakukan 3 siklus.

Metode pembelajaran PQ4R termasuk dari strategi elaborasi dan serasi dengan Anderson J.R yang mengatakan bahawa sesuai dengan namanya metode PQ4R terdiri dari enam langkah yaitu: Preview, Question, Read, Reflect, Recite, Review. Metode PQ4R adalah metode pembelajaran yang digunakan untuk membantu siswa mengingat apa yang mereka baca.

Pehofer dan Roy dalam Ratih Yunita (2016: 8) menyatakan PQ4R strategy is efficient strategy to facilitate comprehending of texts. Based on the statement from Pehofer and Roy, it means that PQ4R strategy is a strategy that can help students in comprehending the text more easily.

Penerapan metode PQ4R dapat mengaktifkan pengetahuan awal siswa dan mengawali proses pembuatan hubungan antara informasi baru dengan apa yang telah diketahui sebelumnya. Dengan melakukan kegiatan membaca, siswa akan memperoleh pengetahuan yang bermanfaat bagi pertumbuhan dan perkembangan daya nalar, sosial, dan emosinya serta hasil belajar siswa menjadi lebih meningkat.

\section{Tabel 2. Indikator Peningkatan Membaca Pemahaman}

\begin{tabular}{ccccc}
\hline \multirow{2}{*}{ NO } & Indikator Kemampuan Membaca & \multicolumn{3}{c}{ Peningkatan } \\
\cline { 3 - 5 } & Pemahaman & Siklus I & Siklus II & Siklus III \\
\hline 1. & Memahami pengertian sederhana & 59,31 & 91,66 & 95,09 \\
2. & Memahami signifikansi atau makna & 65,19 & 70,58 & 74,5 \\
3. & Evaluasi dan penilaian & 81,04 & 84,96 & 85,45 \\
4. & $\begin{array}{c}\text { Kecepatan membaca fleksibel sesuai } \\
\text { keadaan (75 kata per menit) }\end{array}$ & 80,39 & 83,33 & 95,09 \\
\hline
\end{tabular}


Dilihat dari nilai setiap indikator mengalami peningkatan dari siklus I, siklus II dan siklus III. Nilai indikator kedua yaitu memahami signifikansi atau makna mengalami penurunan nilai pada siklus III, meskipun demikian tidak mempengaruhi ketuntasan klasikal. Meskipun terjadi penurunan nilai pada satu indikator di siklus III, akan tetapi pada siklus I dan II terjadi peningkatan ketuntasan klasikal yang cukup signifikan dengan nilai indikator pertama yaitu memahami pengertian sederhana pada siklus I adalah 59,31 meningkat menjadi 91,66 pada siklus II, meningkat kembali pada siklus III sebesar 95,09. Nilai indikator kedua yaitu memahami signifikansi atau makna pada siklus I adalah 65,19 meningkat menjadi 70,58 pada siklus II kemudian meningkat kembali pada siklus III sebesar 74,5. Nilai indikator ketiga yaitu evaluasi dan penilaian pada siklus I adalah 81,04 meningkat menajadi 84,96 pada siklus II kemudian meningkat kembali menjadi 85,45 pada siklus III. Nilai indikator keempat yaitu kecepatan membaca fleksibel sesuai dengan keadaan (75 kata per menit) pada siklus I adalah 80,39 meningkat menjadi 83,33 pada siklus II dan kemudian meningkat kembali menjadi 95,09 pada siklus III.

Hal ini sesuai dengan teori yang di kemukakan oleh Trianto (2007:156) bahwa metode PQ4R (Preview, Question, Read, Reflect, Recite, Review) memiliki beberapa kelebihan salah satunya yaitu dapat mengaktifkan pengetahuan awal siswa ketika membaca sekilas, serta membantu siswa memahami isi bacaan lebih mudah dengan melakukan tahapan PQ4R yaitu (Preview, Question, Read, Reflect, Recite, Review), metode PQ4R juga sangat cocok untuk meningkatkan kemampuan membaca pemahaman, yaitu di setiap tahapan pembelajarannya mampu memotivasi siswa untuk mencari, mengingat, dan memahami informasi yang didapat dari hasil membaca cerita atau bahan bacaan lainnya. Adapun teori pendukung yang menyatakan bahwa metode PQ4R dapat meningkatkan kemampuan membaca pemahaman siswa yaitu, teori yang dikemukakan oleh Teori Konstruktivisme dalam Trianto (2007: 13) menyatakan bahwa metode PQ4R memberikan kesempatan kepada siswa menemukan ide pokok atau gagasan utamanya dengan mandiri sehingga siswa lebih memahami isi bacaan yang telah dibacanya. Dari pendapat di atas dapat disimpulkan bahwa metode PQ4R (Preview, Question, Read, Reflect, Recite, Review) dapat menigkatkan kemampuan membaca pemahaman siswa. 


\section{KESIMPULAN}

Berdasarkan hasil Penelitian Tindakan Kelas (PTK) yang dilakukan di kelas V SDN Cibuntu 06 Bekasi menunjukkan bahwa penerapan metode PQ4R (Preview, Question, Read, Reflect, Recite, Review) dapat meningkatkan kemampuan membaca pemahaman siswa pada mata pelajaran Bahasa Indonesia. Hal ini dapat dilihat dari nilai rata-rata yang diperoleh siswa yang mengalami peningkatan pada setiap siklusnya. Pada siklus I presentase ketuntasan belajar klasikal mencapai 67,64\%. Kemudian, terjadi peningkatan pada siklus II presentase ketuntasan belajar klasikal mencapai $76,47 \%$. Setelah itu pada siklus III dengan presentase ketuntasan belajar klasikal mencapai 94,11\%. Berdasarkan hasil penelitian, ada peningkatan kemampuan membaca pemahaman pada mata pelajaran Bahasa Indonesia setelah diterapkan metode PQ4R (Preview, Question, Read, Reflect, Recite, Review) pada siswa kelas V SDN Cibuntu 06.

Tahapan - tahapan PQ4R dalam meningkatkan membaca pemahaman dimana siswa berperan banyak dalam memahami bacaan, diawali dengan membaca sekilas teks bacaan kemudian berpikir secara mendalam berkaitan dengan teks tersebut dan diakhiri dengan membahas hasil temuannya. Siswa menggabungkan kemampuan membacanya, sehingga mampu berkonsentrasi melalui diskusi yang memberikannya ide-ide berkaitan dengan teks bacaan. Hal ini memberikan siswa kemudahan dalam proses membaca dan dapat meningkatkan proses pemahamannya juga. Sesuai dengan penelitian yang dilakukan oleh Ratih Sari, Sudirman dan Dedy (2016) senada juga dengan hasil telaahan Reem Hasan Al-Qawabeh (2018).

\section{DAFTAR PUSTAKA}

Al-Qawabeh, Reem Hassan \& Abdullah Ali Aljazi. 2018. The Effectiveness of Using PQ4R Strategy in Teaching Reading Comprehension in Arabic Language Subject among Ninth Grade Students' Achievement in Jordan. Jordan: World Journal of Educational Research. SCHOLINK INC.

Arikunto, Suharsimi, dkk. 2009. Penelitian Tindakan Kelas. Jakarta : PT. Bumi Aksara.

Dalman. 2013. Keterampilan Membaca. Jakarta: PT Raja Grafindo Persada.

Ekawarna. 2011. Penelitian Tindakan Kelas. Jakarta: Gaung Persada.

Farida, Rahim. 2007. Pengajaran Membaca di Sekolah Dasar.Jakarta: Bumi Aksara. 
Sari, Ratih Yunita, Sudirman dan Dedy Supriyadi. 2016. The Effect Of PQ4R Strategy In Reading Comprehension Achievement. Online: https://media.neliti.com/media/publications/193977-EN-the-effect-ofpq4r-strategy-in-reading-c.pdf.

Sumiati, Lilis 2015. Pengarub metode SQ3R (Survey, Question, Read, Recite, Review) terhadap kemampuan membaca pemahaman pada mata pelajaran bahasa indonesia kelas V SDN Gandasari 02. Tidak dipublikasikan.

Suprijono, Agus. 2015. Cooperative Learning. Yogyakarta: Pustaka Belajar.

Tampubolon, Saur. 2013. Penelitian Tindakan Kelas. Jakarta: PT Erlangga.

Tarigan, Henry Guntur. 2008. Membaca sebagai suatu keterampilan Berbahasa. Bandung: Percetakan Angkasa.

Trianto, 2014. Mendesain Model Pembelajaran Inovatif, Progresif, dan Kontekstual. Jakarta: Prenadamedia Group.

Yulianti, Eva. 2013. Penerapan Metode PQ4R (Preview, Question, Read, Reflect, Recite, Review) untuk meningkatkan keterampilan membaca pada mata pelajaran bahasa indonesia di SD. Jurnal Pendidikaan Guru Sekolah Dasar Universitas Pendidikan Ganesha Singaraja, Indonesia. 